\title{
O SISTEMA NACIONAL DE EDUCAÇÃO (SNE) E OS ENTRAVES À SUA INSTITUCIONALIZAÇÃO: UMA ANÁLISE A PARTIR DA ABORDAGEM DIREITO E POLÍTICAS PÚBLICAS
}

\section{THE NATIONAL EDUCATION SYSTEM (SNE) AND THE OBSTACLES TO ITS INSTITUTIONALIZATION: AN ANALYSIS FROM THE LAW AND PUBLIC POLICIES APPROACH}

Clarice SEIXAS DUARTE ${ }^{1}$

RESUMO: A Lei 13.005/2014, que estabeleceu o Plano Nacional de Educação (PNE 2014-2024), foi aprovada, por unanimidade, pelo Congresso Nacional, destacandose, na sua elaboração, as contribuições de diversos setores, público e privado, da educação infantil à pós-graduação, cujas propostas foram amplamente debatidas e sistematizadas na Conferência Nacional de Educação (CONAE) 2010. Para o cumprimento de suas diretrizes, metas e estratégias, o PNE 2014-2024 estabeleceu o dever de institucionalização do Sistema Nacional de Educação (SNE), com a fixação de um prazo de dois anos, após sua promulgação, para o cumprimento dessa obrigação. O objetivo do presente artigo é, a partir da abordagem Direito e Políticas Públicas, identificar os principais entraves jurídicos e políticos que impediram a estruturação e normatização do SNE. Trata-se de uma questão complexa, que envolve disputas acerca da regulamentação do federalismo cooperativo em matéria educacional, previsto nos artigos 23 e 211 da CF/88, além de conflitos de natureza distributiva em torno da escolha de prioridades de ação governamental e destinação de recursos públicos. Estima-se estar em jogo um desmonte do modelo de proteção social pactuado durante o processo constituinte, justificando-se, para a identificação e uma melhor compreensão dos pontos de tensão entre os elementos jurídico, político e pragmático-financeiros que estão por trás do problema, a abordagem mencionada.

Palavras-Chave: Sistema Nacional de Educação; Plano Nacional de Educação; Políticas públicas educacionais; Abordagem Direito e Políticas Públicas.

\footnotetext{
${ }^{1}$ Doutora em Filosofia e Teoria Geral do Direito pela USP. Professora dos Programas de Graduação e Pós Graduaçäo stricto sensu em Direito Político e Econômico da Universidade Presbiteriana Mackenzie. E-mail: clarice.duarte@mackenzie.br. Currículo: http://lattes.cnpq.br/3035111705789712.
} 
ABSTRACT: The 13.005/2014 statute, which established the National Education Plan (PNE 2014-2024), was unanimously approved by the National Congress. Relevant for its development were contributions of various sectors involved with education, both public and private, ranging from childhood education to graduate programs. The proposals of these different groups were widely debated and systematized at the 2010 National Conference on Education (CONAE). To comply with PNE 20142024 's guidelines, goals and strategies, 13.005/2014 staute established the duty to institutionalize the National Education System (SNE) after a period of two years after its promulgation. The purpose of this article is, from Law and Public Policy approach, to identify the main legal and political barriers that prevented the structuring and standardization of the SNE. This is a complex issue that involves disputes over the regulation of cooperative federalism in educational matters, provided for in articles 23 and 211 of CF / 88, as well as conflicts of a distributive nature regarding the choice of priorities for government action and the destination of public resources. It is possible that the social protection model, agreed upon during the constituent process, is at stake, thus justifying the approach here proposed, aiming to identify and better understand the tension points among the legal, political and pragmatic-financial elements underlying the problem.

KeYwORDS: National Education System; National Plan of Education; educational public policies; Law and Public Policy approach.

\section{INTRODUÇÃO}

Passados mais de trinta anos da promulgação da Constituição Federal Brasileira de 1988 (CF/88), momento em que os movimentos populares obtiveram grandes conquistas após um longo processo de luta contra os abusos de poder cometidos durante o período da Ditadura Militar, estamos assistindo a uma série de retrocessos em relação aos avanços implementados desde então. O modelo de Estado Social e Democrático de Direito adotado, sintetizado no artigo $3^{\text {o }}$ - fundado na democratização das instâncias de poder e na realização de valores como o da liberdade, igualdade, justiça social e solidariedade - está em xeque. Tais objetivos não podem ser realizados sem a equalização das oportunidades de acesso à educação de qualidade para todos.

Contudo, apesar dos avanços introduzidos pela CF/88, no campo educacional, não houve, naquele momento histórico, um consenso no sentido de estruturação de um sistema nacional de educação (SNE), tal como ocorrido no campo da saúde, com o delineamento do Sistema Único de Saúde (SUS). Foram mantidas formas de organização da educação em âmbitos federal, estadual e municipal autônomas e desconectadas, na contramão do espírito do federalismo cooperativo, também 
previsto no texto constitucional, que visa promover uma maior aproximação entre a União e os demais entes federativos, no sentido de realização do princípio da solidariedade (BERCOVICI, 2003).

Em que pese a previsão constitucional, até hoje a regulamentação do regime de colaboração em matéria educacional não foi realizada. A EC 59/09, ao alterar os art. 214 da CF/88, criou uma oportunidade histórica para a organização e estruturação da educação, estabelecendo, como grande objetivo do Plano Nacional de Educação, a articulação do Sistema Nacional de Educação.

A redação original do art. 214 da CF/88 já anunciava o PNE como uma política de longo prazo, de duração plurianual, que passaria a definir a agenda das políticas públicas educacionais brasileiras. Mas o que significou a novidade introduzida pela EC 59/2009, com a previsão do SNE vinculada ao PNE? Para responder essa questão, é preciso compreender em que consiste (SAVIANI, 2010; CURY, 2018), a que e a quem serve o SNE.

Uma das grandes finalidades do SNE, em consonância com os objetivos do art. $3^{\text {o }}$ da $\mathrm{CF} / 88$, é combater, em matéria educacional, as diferenças regionais, entre estados de uma mesma região, e ainda entre municípios do mesmo estado. Afinal, aquelas pessoas que nasceram em localidades menos desenvolvidas economicamente têm igual direito a uma educação pública de qualidade em relação àqueles que vivem em áreas mais abastadas.

$\mathrm{O}$ presente artigo pretende identificar e analisar os principais entraves à institucionalização de um SNE no Brasil, apesar de sua previsão expressa no ordenamento jurídico, seja no plano constitucional (art. 214), seja no plano infraconstitucional, por meio da Lei 13.005/2014, que estabeleceu o Plano Nacional de Educação (PNE) 2014-2024, cujas consequências recaem sobre o adiamento indefinido da satisfação das necessidades educacionais do país (SAVIANI, 2010).

Trata-se de um desafio que justifica a abordagem Direito e Políticas Públicas (BUCCI; COUTINHO, 2017; BUCCI; DUARTE, 2017), metodologia que permite o exame e uma melhor compreensão dos fatores que dificultam o enfrentamento de um problema jurídico complexo, interdisciplinar e de larga escala, cuja solução demanda intervenção governamental estruturada, voltada à realização de determinados fins socialmente relevantes e politicamente determinados (BUCCI, 2013). No caso, trata-se dos desafios para a criação de um sistema nacional de educação.

Nesse contexto, a análise das questões jurídicas que envolvem o tema deve ser combinada à busca de fatores extrajurídicos que influenciam determinadas escolhas políticas. Afinal, as instituições estão inseridas em um mundo concreto, em que há inúmeras disputas de interesses e visões de mundo, e estes elementos precisam ser analisados e levados em conta para a compreensão das decisões que envolvem políticas públicas.

Partiu-se de uma análise do conceito de sistema aplicado à educação utilizandose a formulação de Saviani (2010), passando-se pelo exame dos principais debates 
em torno da incorporação do tema ao cenário jurídico brasileiro, desde a década de 1930 até os dias atuais, que refletem uma série de disputas históricas em relação a diferentes concepções sobre a natureza, as finalidades e os mecanismos de garantia do direito à educação, capitaneadas por diferentes atores políticos e sociais.

\section{CONCEITO, ORIGENS E EVOLUÇão HISTÓRICA DO SISTEMA NACIONAL DE EDUCAÇÃO NO BRASIL: DO MANIFESTO DOS PIONEIROS DA EDUCAÇÃO NOVA, DE 1932, AOS DIAS ATUAIS}

A determinação do conceito de sistema nacional de educação é tarefa árdua, pois há muita imprecisão e pouco consenso nessa área. Ele está ligado à defesa da escola pública, universal, gratuita, obrigatória e laica, bandeiras que se difundiram sobretudo a partir da Revolução Francesa. Tais ideais só se tornaram realidade a partir da segunda metade do século XIX, quando o modo encontrado para se erradicar o analfabetismo e universalizar a instrução popular foi a organização, por parte dos Estados, de sistemas educacionais nacionais (SAVIANI, 2010).

O Brasil, diferentemente de outros países da Europa, América do Norte e até mesmo da América Latina - dentre os quais a Argentina, o Chile e o Uruguai - não implantou um sistema nacional de educação no decorrer do século XIX, adiando constantemente a resolução de problemas basilares no campo educacional.

Mas, afinal, o que é um sistema nacional de educação e como ele pode vir a contribuir para a melhoria dos índices acima apontados?

Para entender o significado da expressão, convém, em primeiro lugar, afastar algumas imprecisões conceituais em torno do tema. Segundo a proposta de conceituação de Saviani (2010), sistema não é o mero agrupamento de um conjunto de elementos formando um todo, de modo que a mera reunião de unidades escolares não compõe um sistema educacional. Quando nos referimos à reunião de escolas municipais, ou particulares, por exemplo, estamos falando da rede municipal ou particular de ensino, e não do "sistema municipal" ou do "sistema particular" de ensino, embora seja comum o uso indevido da expressão.

A configuração de um sistema depende da existência de algo que una os seus elementos constitutivos, e esse "algo" é justamente a finalidade comum que deve guiar as atividades das unidades que compõem o todo. Por outro lado, num sistema, a reunião dessas atividades não ocorre ao acaso, mas é fruto de uma ação intencional e, mais do que isso, ela ocorre "segundo normas decorrentes dos valores que estão na base da finalidade preconizada. Assim, sistema implica organização sob normas próprias (o que lhe confere um elevado grau de autonomia) e comuns (isto é, que obrigam a todos os seus integrantes)" (SAVIANI, 2010).

Não faz sentido, portanto, segundo a formulação de Saviani, falar em um "sistema particular de ensino" e um "sistema público de ensino". Existe apenas um sistema educacional que, por definição, deve ser público, pois apenas o Estado tem competência para criar normas que obrigam a todos os integrantes do sistema. 
Nesse sentido, as escolas particulares integram o sistema público de ensino justamente porque se subordinam a regras comuns aplicáveis a todos os entes federativos emanadas pela União:

(...) construir um verdadeiro sistema, isto é, um conjunto unificado que articula todos os aspectos da educação no país inteiro, com normas comuns válidas para todo o território nacional e com procedimentos também comuns, visando a assegurar educação com o mesmo padrão de qualidade a toda a população do país. Não se trata, portanto, de se entender o Sistema Nacional de Educação como um grande guarda-chuva com a mera função de abrigar 27 sistemas estaduais de ensino, incluído o do Distrito Federal, o próprio sistema federal de ensino e, no limite, 5.565 sistemas municipais de ensino, supostamente autônomos entre si. Se for aprovada uma proposta nesses termos, o Sistema Nacional de Educação se reduzirá a uma mera formalidade, mantendo-se, no fundamental, o quadro de hoje com todas as contradições, desencontros, imprecisões e improvisações que marcam a situação atual, de fato avessa às exigências da organização da educação na forma de um sistema nacional (SAVIANI, 2010).

A criação de um verdadeiro SNE não significa, portanto, a mera união formal, aleatória e espontânea de diferentes redes de ensino. Ela depende de uma decisão que implica em mudanças concretas no modelo de organização, estruturação, articulação interna e direcionamento da educação brasileira. Para tanto, é preciso garantir uma maior e mais qualificada colaboração da União, voltada a guiar a ação e o comportamento dos componentes e elementos do sistema para a realização de finalidades comuns, estabelecendo normas que deverão ser cumpridas por todos os integrantes do sistema.

Diferentemente do que ocorreu nos países acima citados que adotaram, já no século XIX, o modelo de sistemas nacionais de educação, no Brasil apenas na década de 1930, com o Manifesto dos Pioneiros da Educação Nova, de 1932, foi que surgiu o debate em torno da necessidade de se promover uma ampla renovação educacional, em "reação categórica, intencional e sistemática contra a velha estrutura do serviço educacional" (AZEVEDO et al, 1932, p. 40). Resultante de uma sucessão periódica de reformas parciais, fragmentadas e desarticuladas, lançadas sem solidez econômica e sem uma visão global do problema educacional em todos os seus aspectos, o antigo modelo precisava ser substituído (AZEVEDO et al, 1932, p. 33). O novo paradigma, comprometido com a defesa da escola pública, gratuita, universal, laica e de qualidade, parte do reconhecimento da função social da educação, a ser organizada pelo Estado para a coletividade em geral, e não somente 
àqueles dotados de privilégios determinados por sua condição econômica. Segundo essa concepção:

(...) cabe evidentemente ao Estado a organização dos meios de o tornar efetivo [o direito de cada indivíduo a sua educação integral], por um plano geral de educação, de estrutura orgânica, que torne a escola acessível, em todos seus graus, aos cidadãos a quem a estrutura social do país mantém em condições de inferioridade econômica para obter o máximo de desenvolvimento de acordo com suas aptidões vitais. Chega-se, por essa forma, ao princípio da educação para todos, "escola comum ou única", que, tomado a rigor, só não ficará na contingência de sofrer quaisquer restrições, em países em que as reformas pedagógicas estão intimamente ligadas com a reconstrução fundamental das relações sociais. (AZEVEDO et al, 1932, p. 44).

Àquela época, os escolanovistas, como eram chamados os signatários do Manifesto - dentre eles Fernando de Azevedo, Anísio Teixeira, Lourenço Filho e Cecília Meirelles -, acreditavam que a unidade educacional não dependia de um centralismo que ignorasse as condições geográficas do país e a necessidade de adaptação das escolas aos interesses e às exigências regionais: “(...) não é, pois, na centralização, mas na aplicação da doutrina federativa e descentralizadora que teremos de buscar o meio de levar a cabo, em toda a República, uma obra metódica e coordenada, de acordo com um plano comum" (AZEVEDO et al, 1932, pp. 47-8).

A Constituição Federal de 1934 incorporou as concepções dos Pioneiros da Educação Nova, cujo principal objetivo imediato era influenciar a Assembleia Nacional Constituinte, de 1933, no sentido de incluir no texto constitucional o direito à educação como um dever a ser assegurado pelo Estado e instituir uma organização sistêmica da educação nacional (BUCCI e GOMES, 2017, p. 279).

$\mathrm{O}$ documento contou com todo um capítulo destinado à educação, no qual foram estabelecidos os princípios, fundamentos e as orientações gerais da educação nacional, cujo cumprimento seria fiscalizado pelo Governo Central, por meio da atuação do Ministério da Educação. Um outro avanço introduzido no período foi a previsão da vinculação constitucional de receitas a serem aplicadas exclusivamente em educação, dispositivo que se manteve em todas as constituições democráticas brasileiras.

A Constituição Federal de 1934 também cuidou de fixar as competências em matéria educacional da União, na capital, e dos estados, nos seus respectivos territórios. Cabia à União: a) a atribuição de legislar sobre as diretrizes da educação nacional, criando normas comuns válidas para toda a nação; $b$ ) a função de socorrer os estados onde houvesse deficiência de meios e, ainda c) a promoção do intercâmbio pedagógico e cultural dos Estados. 
A unidade educativa seria dada justamente pela atuação solidária e cooperativa da União, configurando-se, assim, a sua organização na forma de um sistema (SAVIANI, 2010). Pretendia-se contribuir para resolver o que consideravam o problema fundamental das democracias, a educação das massas populares, e não apenas das elites formadas artificialmente por diferenciação econômica.

Contudo, com o advento do Estado Novo e a Carta de 1937, a ideia de criação de um sistema nacional de educação nos moldes acima enunciados se perdeu. Nesse sentido, de acordo com Jamil Cury (2018), o Estado Novo representou um óbice à concretização do que a Constituição de 1934 previra para a educação, sobretudo no que diz respeito ao ideal de um plano para o setor nela previsto.

A partir da redemocratização do país e da promulgação da Constituição Federal de 1946, embora tenha-se atribuído à União o dever de legislar sobre diretrizes e bases da educação nacional, a ideia da organização de um sistema nacional de educação não foi assegurada, pois prevaleceu a tese de que tal forma de estruturação da educação nacional levaria a uma excessiva centralização do ensino. Ainda assim, o texto retomou avanços introduzidos pela Constituição de 1934, concebendo o planejamento e a regulação da educação como atividades distintas.

Mas talvez a principal contribuição da Constituição de 1946 em matéria educacional tenha sido determinar, expressamente, de maneira pioneira, que o dever de cooperação do Governo Federal com os "sistemas" educacionais dos governos subnacionais deveria se dar na forma de assistência financeira (BUCCI e GOMES, 2017, p. 281). Com isso, pode-se afirmar que, na prática, desde a Constituição Federal de 1946, o embrião do princípio do federalismo cooperativo já havia sido introduzido em nosso ordenamento jurídico (COMPARATO, 1987).

A oposição entre centralização e descentralização do ensino tornou-se ainda mais acirrada durante os debates que antecederam a promulgação da nossa primeira Lei de Diretrizes e Bases da Educação Nacional (LDB), Lei no 4.024, de 1961. Àquela época, prevaleceu a tese da descentralização, com a regulamentação de "sistemas" estaduais de ensino, admitindo-se o "sistema" federal apenas em caráter supletivo. Outro fator que contribuiu para se manter afastada a ideia da criação de um SNE foi a pressão das escolas particulares, capitaneadas pela Igreja Católica, que temiam perder sua força, pois acreditavam que tal forma de organização levaria ao monopólio estatal do ensino (SAVIANI, 2010).

Ora, como já alertavam os Pioneiros da Educação Nova:

(...) em nosso regime político, o Estado não poderá, decerto, impedir que, graças à organização de escolas privadas de tipos diferentes, as classes mais privilegiadas assegurem a seus filhos uma educação de classe determinada, mas está no dever indeclinável de não admitir, dentro do sistema escolar do Estado, quaisquer classes ou escolas, a que só tenha acesso uma minoria, por um privilégio exclusivamente econômico. Afastada a ideia de 
monopólio da educação pelo Estado, num país em que o Estado, pela sua situação financeira não está ainda em condições de assumir sua responsabilidade exclusiva, e em que, portanto, se torna necessário estimular, sob sua vigilância, as instituições privadas idôneas (...) (AZEVEDO et al, 1932, p. 44).

Na realidade, as discussões sobre a primeira LDB, de 1961, no Congresso Nacional foram marcadas por intensas divergências entre grupos que tinham visões contrapostas sobre a natureza e os objetivos da educação, o que se traduzia na assimetria de posicionamentos acerca da natureza e dos objetivos da própria LDB. Na ocasião, prevaleceu o entendimento dos que defendiam o caráter lucrativo empresarial da educação, que deveria estar voltada sobretudo para a produção de resultados econômicos, não apenas para a escola em si mesma, mas também para os educandos (educação voltada para o mercado de trabalho) (COMPARATO, 1987).

A posição da campanha da Associação das Escolas Católicas, fundada na liberdade do ensino no sentido empresarial, também rechaçava a ideia de um intervencionismo forte do Estado no campo educacional com vistas à realização de objetivos sociais. Segundo essa concepção, o poder público deveria limitar-se à fiscalização, avaliação e ao controle da educação (COMPARATO, 1987). Nesse contexto, a possibilidade de se introduzir um tratamento sistêmico da educação em nível nacional via LDB não encontrou terreno fértil para se desenvolver.

De acordo com Saviani (2010), faria todo o sentido estruturar um sistema nacional de educação em uma lei que trata das diretrizes (que correspondem aos fins ou rumos para onde se quer caminhar) e bases (que se referem aos meios pelos quais os fins serão atingidos) da educação nacional. Isso porque tal documento jurídico deve prever as normas e metas aplicáveis a todos os entes federativos, guiando a sua atuação para o cumprimento dos grandes objetivos educacionais (respeitando-se os parâmetros que já haviam sido estabelecidos pela Constituição de 1946), de acordo com os meios à disposição do Estado. Contudo, na ocasião, optou-se pela criação de um novo instrumento para tratar do tema, autônomo em relação à LDB: o primeiro Plano Nacional de Educação brasileiro:

O primeiro Plano Nacional de Educação surgiu em 1962, elaborado já na vigência da primeira Lei de Diretrizes e Bases da Educação Nacional, Lei no 4.024, de 1961, uma iniciativa do Poder Executivo, referendada pelo Conselho Federal de Educação. Preocupou-se em fixar metas quantitativas e qualitativas que deveriam ser alcançadas num prazo de oito anos e critérios para a destinação de recursos. Em 1965, sofreu uma revisão, quando foram introduzidas normas descentralizadoras e estimuladoras da elaboração de planos estaduais e o salário educação. Em 1966, uma nova revisão, 
que se chamou Plano Complementar de Educação, introduziu importantes alterações na distribuição dos recursos federais, beneficiando a implantação de ginásios orientados para o trabalho e o atendimento de analfabetos com mais de dez anos (ALVES, 2010)

Todavia, apesar das expectativas, o PNE de 1962 teve vida curta, pois logo no início de sua vigência deu-se o golpe militar de 1964, oferecendo novos parâmetros para a educação no Brasil, com a prevalência do pensamento tecnocrático no campo educacional (DOURADO, 2018). A Constituição de 1967 conferiu grande estímulo à privatização do ensino, de modo que a concepção empresarial da educação foi reforçada. No período, houve o aumento da porcentagem de fundos públicos federais destinados às escolas particulares e foi criado o salário-educação como medida substitutiva da obrigação imposta às empresas com um número mínimo de empregados de assegurarem a instrução primária dos filhos dos empregados. Nesse campo houve uma série de desvios, tais como a criação de escolas fantasmas e a indicação de "almas mortas" para se beneficiarem das bolsas de estudo (COMPARATO, 1987, p. 110).

Além disso, ainda no período ditatorial, por meio da Lei $\mathrm{n}^{\mathrm{o}} 5.540$, de 28 novembro de 1968, estabeleceram-se normas de organização e funcionamento do ensino superior e da sua articulação com a escola média. Tais normas advinham do Acordo denominado MEC/USAID e foram chamadas de "Reforma Universitária". O discurso era pela busca por autonomia didático-científica, disciplinar, administrativa e financeira às universidades; no entanto seus efeitos, conforme Regina Gadelha (2017), direcionavam-se à massificação do ensino.

Com o fim do Regime Militar e a redemocratização, perdeu-se a oportunidade de se instituir, já no texto constitucional de 1988, uma nova forma de estruturação educacional, por meio da criação de um sistema único de abrangência nacional. Diferentemente do ocorrido no campo da saúde, não houve, naquele momento histórico, um consenso em torno do reconhecimento da importância da criação de um sistema nacional como forma de estruturar as redes e serviços de ensino então existentes, que funcionavam de forma autônoma e desarticulada.

Mesmo sem ter havido consenso em torno da previsão expressa de um sistema nacional de educação no texto original da CF/88, o art. 23 estabeleceu a competência comum da União, dos Estados, do Distrito Federal e dos Municípios no sentido de proporcionar os meios de acesso à cultura, à educação, à ciência, à tecnologia, à pesquisa e à inovação (inciso V). Determinou, ainda, no parágrafo único do mesmo dispositivo, que as normas para a cooperação entre a União e os Estados, o Distrito Federal e os Municípios, tendo em vista o equilíbrio do desenvolvimento e do bemestar em âmbito nacional, deveriam ser fixadas por lei complementar.

No mesmo sentido, o artigo 211 estabeleceu que a União, os Estados, o Distrito Federal e os Municípios organizarão, em regime de colaboração, seus sistemas de 
ensino, cabendo: à União a organização dos sistemas federal de ensino e o dos Territórios, o financiamento das instituições de ensino públicas federais e o exercício da função redistributiva e supletiva em matéria educacional, de maneira a garantir a equalização de oportunidades educacionais e padrão mínimo de qualidade de ensino, mediante assistência técnica e financeira aos entes federativos $\left(\S 1^{o}\right)$; aos Municípios, a atuação prioritária no ensino fundamental e na educação infantil $\left(\S 2^{\circ}\right)$ e aos Estados e ao DF a atuação prioritária no ensino fundamental e médio $\left(\S 3^{\circ}\right)$. $\mathrm{O} \S 4^{\circ}$ estabelece que, na organização de seus sistemas de ensino, a União, os Estados, o DF e os Municípios definirão formas de colaboração, de modo a assegurar a universalização do ensino obrigatório.

Já as diretrizes para aplicação e distribuição dos recursos públicos na esfera educacional foram previstas nos artigos 212 e 213, sendo que o artigo 212 estabelece as regras sobre a participação dos entes federativos no financiamento do sistema de ensino. A União não poderá aplicar menos de 18\% e os Estados, Distrito Federal e os Municípios não poderão aplicar menos de $25 \%$ da receita resultante de impostos, na manutenção e desenvolvimento do ensino.

No federalismo cooperativo, nem a União nem qualquer ente federado pode atuar isoladamente, mas todos devem exercer sua competência conjuntamente com os demais (...) Na repartição de competências, a cooperação se revela nas chamadas competências comuns, consagradas no art. 23 da Constituição de 1988. Nas competências comuns, todos os entes da Federação devem colaborar para a execução das tarefas determinadas pela Constituição. E mais: não existindo supremacia de nenhuma das esferas na execução dessas tarefas, as responsabilidades também são comuns, não podendo nenhum dos entes da Federação se eximir de implementá-las, pois o custo político recai sobre todas as esferas de governo. A cooperação parte do pressuposto da estreita interdependência que existe em inúmeras matérias e programas de interesse comum, o que dificulta (quando não impede) a sua atribuição exclusiva ou preponderante a um determinado ente, diferenciando, em termos de repartição de competências, as competências comuns das competências concorrentes e exclusivas (BERCOVICI, 2002).

No Brasil, a União é o ente federativo que mais arrecada, tendo, dessa forma, o dever constitucional de compensar os desequilíbrios que se expressam nas disparidades da oferta de serviços educacionais no país. Cabe à União direcionar a sua atuação para o cumprimento das finalidades do Estado Social instaurado com a $\mathrm{CF} / 88$, notadamente a redução das desigualdades existentes na sociedade e a realização da justiça social (cf. dentre outros, a síntese prevista no art. $3^{\text {o }}$ da CF/88). 
Ocorre que a União vem, no desempenho de sua responsabilidade no campo educacional, atuando de forma muito mais subsidiária do que supletiva e redistributiva, deixando em segundo plano o caráter solidário de sua intervenção. Na realidade cotidiana, os municípios, entes federativos que menos arrecadam vêm assumindo atribuições em matéria educacional desproporcionais em relação à sua arrecadação, sobretudo a partir do movimento de descentralização da educação, iniciado na década de 1990. Eis aí uma inversão do princípio do federalismo cooperativo.

Diante das distorções que o modelo desconcentrado de prestação de serviços educacionais pode gerar, o debate sobre a institucionalização de um sistema nacional de educação foi retomado após a promulgação da CF/88. Uma nova oportunidade nesse sentido apareceu por ocasião da discussão sobre a elaboração da nova Lei de Diretrizes e Bases da Educação nacional, a Lei no 9.394, sancionada em dezembro de 1996. Contudo, mais uma vez, a chance não foi aproveitada. Constou da nova LDB apenas um capítulo tratando da "Organização da Educação Nacional", sem conferir aos elementos desse todo a articulação de um verdadeiro SNE.

É verdade que o projeto inicial da nova LDB previa um papel de destaque para o Conselho Nacional de Educação (CNE), secundado pelo Fórum Nacional de Educação. Contudo, no Substitutivo Darcy Ribeiro, a previsão do Fórum Nacional de Educação foi retirada e o CNE, diferentemente da concepção que havia prevalecido na Câmara, deixou de ser uma instância com funções deliberativas no âmbito da educação. Segundo Saviani (2010), isso se deveu ao posicionamento tanto do governo Collor, quanto do governo Fernando Henrique Cardoso, no sentido de que a atribuição de caráter deliberativo às decisões do CNE diminuiria a importância do MEC na tarefa de formular a política nacional de educação.

Com a ausência de tratamento sistemático da educação pela nova LDB e após o fracasso do plano de 1962, somente em 2001 foi instituído o primeiro PNE por lei no Brasil, de duração decenal. A elaboração do documento contou com a participação do governo federal, de parlamentares e dos chamados "interlocutores prioritários" - Undime (União Nacional dos Dirigentes Municipais de Educação) Consed (Conselho Nacional de Secretários de Educação) e a CNTE (Confederação Nacional dos Trabalhadores em Educação) (MARTINS, 2014, p. 17).

Em que pese a importância da iniciativa, as metas orçamentárias previstas no PNE 2001-2010 foram objeto de veto pelo então Presidente da República, o que acabou inviabilizando o cumprimento de suas demais metas, por falta de recursos, tornando-o inócuo. Na prática, as fontes e os caminhos de financiamento, embora originalmente indicados no PNE 2001-2010, acabaram sendo esvaziados, impossibilitando que tal instrumento trouxesse alterações importantes no quadro da estrutura educacional brasileira.

Foi apenas a partir de um processo de ampla mobilização popular que a previsão de um SNE veio a ser incorporada ao ordenamento jurídico brasileiro, 
num processo que foi consagrado com a promulgação da EC 59/2009. Esse diploma, ao alterar o artigo 214 da $\mathrm{CF} / 88$, estabeleceu de maneira expressa o vínculo entre o Plano Nacional de Educação e o SNE. A Emenda foi responsável por fazer com que os planos decenais de educação passassem à condição de instrumentos de planejamento que ultrapassam períodos de governo, abrangendo todo o território nacional e compreendendo todos os níveis, etapas e modalidades de ensino. (BRASIL, 2016).

A nova redação do art. 214 passou a dispor que a lei deverá estabelecer o plano nacional de educação, de duração decenal, com o objetivo de articular o sistema nacional de educação em regime de colaboração e definir diretrizes, objetivos, metas e estratégias de implementação para assegurar a manutenção e o desenvolvimento do ensino em seus diversos níveis, etapas e modalidades, por meio de ações integradas dos poderes públicos das diferentes esferas federativas.

Ocorre que, tal como observado por Saviani (2010), a EC 59/2009 apresenta uma certa impropriedade. Isso porque, segundo o autor, atribuir ao PNE a função de articular um SNE implica admitir a existência prévia de um sistema (o objeto que deve ser articulado). Mas, se o suposto sistema existente carece de articulação, isso significa, de acordo com o conceito proposto por Saviani, que não estamos diante de um sistema. A questão, para além de revelar um problema conceitual, aponta também uma questão de relevância prática. Isso porque sem o sistema - que tem caráter permanente e deveria preceder o plano - o cumprimento das metas do PNE fica prejudicado, pois é a partir da existência daquele que este deveria se apoiar para alcançar suas metas (SAVIANI, 2018).

No próximo tópico, analisaremos o debate provocado pelo PNE 2014-2024, estabelecido pela Lei 13.005/14, em torno da necessidade de institucionalização do SNE, e os principais fatores que vêm contribuindo para o seu descumprimento.

\section{PRINCIPAIS ENTRAVES À INSTITUCIONALIZAÇÃo Do SNE, PREVISTO NO PNE 13.005/2014, NO CENÁRIO ATUAL}

\section{Razões de ordem econômico-financeira}

O Plano Nacional de Educação (PNE), instituído pela Lei no 13.005/2014 - o segundo PNE brasileiro aprovado por lei -, de duração decenal, é um instrumento de planejamento do Estado brasileiro que deve orientar a execução e o aprimoramento de políticas públicas nesta área. O documento, previsto no art. 214 $\mathrm{da} \mathrm{CF} / 88$, foi produzido após amplos debates entre diversos atores sociais e o poder público, dos quais resultaram um conjunto de 10 diretrizes, 20 metas e 254 estratégias para assegurar a manutenção e o desenvolvimento do ensino em seus diversos níveis, etapas e modalidades, por meio de ações integradas dos poderes públicos das diferentes esferas federativas.

As 20 Metas preconizadas estão distribuídas segundo as seguintes temáticas: (1) Educação Infantil; (2) Ensino Fundamental; (3) Ensino Médio; (4) Educação 
Especial/Inclusiva; (5) Alfabetização; (6) Educação integral; (7) Aprendizado adequado na idade certa; (8) Escolaridade Média; (9) Alfabetização e alfabetismo funcional de jovens e adultos; (10) EJA integrado à Educação Profissional; (11) Educação Profissional; (12) Educação Superior; (13) Titulação de professores da Educação Superior; (14) Pós-graduação; (15) Formação de Professores; (16) Formação continuada e pós-graduação de professores; (17) Valorização do Professor; (18) Plano de Carreira Docente; (19) Gestão Democrática e (20) Financiamento da Educação.

Além do caráter democrático que marcou o processo de criação do PNE, devese destacar que a lei no 13.005/2014 foi aprovada no Congresso Nacional após a realização de diversos seminários e audiências públicas, tanto na Câmara dos Deputados, quanto no Senado Federal. Foi também sancionada sem vetos pela então Presidente da República, Dilma Rousseff. Esses dados revelam a legitimidade social e política alcançadas pelo documento, além do consenso em relação a relevantes temas da educação nacional no momento de sua entrada em vigor.

Outro aspecto que merece destaque em relação ao PNE 2014-2024 foi o estabelecimento do dever de articulação do Sistema Nacional de Educação em regime de colaboração como seu objetivo principal. Esta inovação, conforme acima mencionado, foi acrescida ao texto original do art. 214 da $\mathrm{CF} / 88$ pela Emenda Constitucional n. 59/2009.

Houve muita expectativa em torno da aprovação de lei complementar regulamentando o art. 23, parágrafo único, da $\mathrm{CF} / 88$, que deveria definir as normas para a cooperação entre a União, os estados, o DF e os municípios no âmbito educacional, tal como mencionado acima. $O$ art. $7^{\circ}$ da Lei $n^{0} 13.005 / 2014$, que aprovou o PNE, previu expressamente a necessidade de atuação conjunta dos entes federados, visando o alcance das metas e estratégias do plano. $\mathrm{O}$ termo "regime de colaboração" aparece 21 vezes no texto da referida lei.

O PNE, ao definir diretrizes, metas e estratégias para o decênio 2014-2024 sinaliza o fortalecimento do regime de colaboração entre os entes federativos por meio da instituição do SNE, de instâncias permanentes de negociação, cooperação e pactuação, da articulação entre o PNE e os planos decenais de estados, Distrito Federal e municípios, da gestão democrática, dos sistemas de avaliação, da valorização dos profissionais da Educação, do financiamento. As políticas de Estado para a superação das práticas patrimonialistas no campo vão requerer o enfrentamento dos limites ao federalismo atual para um federalismo cooperativo, inclusive no campo educacional. (DOURADO, 2018)

Contudo, passado o prazo de dois anos (vencido em junho de 2016) previsto para sua regulamentação e cinco anos da vigência da Lei 13.005/2014, o dever de 
institucionalização do SNE - instrumento que deveria regulamentar o regime de colaboração federativa em matéria educacional - ainda não foi cumprido. Foram elaborados Projetos de Lei tratando da matéria, sendo que o principal tema objeto de polêmica no debate legislativo sobre a formalização do SNE refere-se ao modelo de financiamento da educação a ser adotado (DOURADO, 2018, p. 492), ao qual se articula a delimitação do papel complementar e suplementar da União em matéria educacional e a determinação do conteúdo do chamado "custo aluno qualidade" (CAQ).

A questão do modelo de financiamento da educação, atualmente, está fortemente atrelada ao debate sobre o CAQ, instrumento criado a partir de um amplo debate entre diversos setores educacionais, culminando na formulação contida no documento final da CONAE 2010, previsto nas estratégias 20.6, 20.7, 20.8 e 20.10 da Meta 20 do PNE para calcular o valor potencial que deve ser investido por aluno durante o período de um ano por etapa e modalidade de ensino na educação básica. Tal mecanismo deve garantir que a educação básica pública se realize com base em um padrão mínimo de qualidade, funcionando como uma alternativa ao atual desequilíbrio regional na oferta da educação básica pública (CONAE, 2010, p. 104).

Como um primeiro passo para se atingir uma educação de qualidade no Brasil, a estratégia 20.6 previu, ainda, o chamado "custo aluno qualidade inicial" (CAQi), a ser implantado no prazo de dois anos da vigência do PNE. Ainda que esteja longe do padrão de qualidade educacional alcançado em países da Organização para Cooperação e Desenvolvimento Econômico (OCDE), a previsão do CAQi representou um avanço, na medida em que o instrumento permite atrelar o debate sobre financiamento da educação no país à garantia de padrões de qualidade mínimos, devendo o seu valor ser progressivamente reajustado até a implementação plena do custo aluno qualidade (CAQ).

Para a definição do valor do CAQi, foi estabelecida uma metodologia, fruto de uma parceria entre o Conselho Nacional de Educação (CNE) e a Campanha Nacional de Educação. Tal metodologia baseou-se na consideração dos insumos indispensáveis ao processo de ensino-aprendizagem, tomando como referência o conjunto de padrões mínimos estabelecidos na legislação educacional brasileira, tendo sido aprovada pela Conferência Nacional de Educação Básica 2008 (CONEB) e pela CONAE 2010, e posteriormente normatizada pelo CNE no Parecer CEB/CNE 8/2010, que trata da aplicação do inciso IX do artigo $4^{\circ}$ da Lei nº 9.394/96 (LDB), ao estabelecer critérios para a determinação de padrões mínimos de qualidade de ensino para a educação básica pública.

Apesar dos avanços no processo de elaboração do Parecer CEB/CNE 8/2010, marcado pela parceria entre a sociedade civil organizada e o poder público, o mesmo, após aguardar homologação do Ministério da Educação por quase uma 
década, foi revogado pelo Parecer CNE/CEB no 3/2019². Diante da falta de uma proposta estabelecendo um critério alternativo para o cálculo do CAQi estima-se que o cumprimento das metas do PNE e do dever de institucionalização do SNE foram mais uma vez adiados para um futuro incerto.

Um outro exemplo que ilustra a contrariedade do Poder Executivo à institucionalização do CAQi foi o veto presidencial na Lei de Diretrizes Orçamentárias de 2018:

Do ponto de vista econômico-financeiro, atualmente, pode-se verificar, novamente, um esquecimento do PNE, inclusive com veto presidencial, na lei 13.473 de 8 de agosto de 2017, das diretrizes orçamentárias de 2018, ao custo-aluno-qualidade inicial, ponto crucial para o PNE. A razão do veto foi explicitada por conta do ajuste fiscal: a medida restringiria a discricionariedade alocativa do Poder Executivo na implementação das políticas públicas e reduziria a flexibilidade na priorização das despesas discricionárias em caso de necessidade de ajustes previstos na Lei Complementar no 101/2000 (LRF), colocando em risco o alcance da meta fiscal (BRASIL, 2017). Mais uma vez, a tensão entre o ajuste fiscal e a prestação de direitos sociais pende para o primeiro sinalizando um retrocesso no âmbito dos direitos (CURY, 2018).

Na realidade, a polêmica em torno dos critérios para a determinação do CAQi e do financiamento das metas e dos prazos do PNE tornou-se particularmente delicada a partir da adoção da política de ajuste fiscal atualmente vigente, iniciada durante o governo Temer, consubstanciada na Emenda Constitucional 95/2016, que

\footnotetext{
2 Para fins informativos, é interessante sobre o assunto a notícia veiculada em março de 2019 pela Folha de São Paulo: “"Cinco ex-presidentes da Undime (órgão que representa secretários municipais de Educação) assinaram carta contra a revogação do parecer. Segundo a carta, o dispositivo "altera a lógica do financiamento da educação, saindo do que é distribuído e é insuficiente em termos orçamentários para aquilo que é necessário para o financiamento adequado da educação básica pública de qualidade". O Comitê Técnico da Educação do Instituto Rui Barbosa, que congrega os 33 Tribunais de Contas do país, também questionou o CNE. "[Sustentamos] a necessária discussão pública e democrática do tema, incluindo atores institucionais e da sociedade civil, não apenas visando a evitar retrocessos em matéria assentada legal e constitucionalmente, mas buscando a efetiva implantação do CAQi", diz nota do órgão. Críticos ao parecer do CNE dizem que a lista de insumos previstos no documento não necessariamente traduziria melhora efetiva de qualidade. Segundo Maria Helena Guimarães de Castro, que faz parte da composição atual do CNE, caberia somente ao MEC ou ao Congresso definir o assunto. "O Conselho tem consciência e convicção legal e jurídica de que não é atribuição do CNE definir o custo-aluno, [ao indicar] despesas sem definir de onde vai sair o dinheiro", diz ela, que foi secretária executiva do MEC no governo Michel Temer."
} 
alterou o Ato das Disposições Constitucionais Transitórias, impondo sérios limites às políticas sociais, por razões de contenção de gastos.

Em dezembro de 2016, foi promulgada a Emenda Constitucional 95/2016, que institui um "Novo Regime Fiscal" (estabelecendo o que se convencionou chamar de "teto de gastos"). Segundo o novo texto constitucional, ficam congelados todos os gastos federais por 20 anos, sujeitos a reajustes no limite da inflação do ano anterior. Na prática, esta emenda - uma medida drástica sem precedentes limita a expansão do gasto social por 20 anos, inviabilizando a implementação do Plano Nacional de Educação (PNE) e da expansão do Sistema Único de Saúde (SUS) e de programas da assistência social, entre outras políticas centrais para o combate à pobreza e às desigualdades no Brasil. Isto ocorrerá justamente em um período durante o qual a população brasileira vai se expandir e envelhecer mais, e em meio a uma grave crise econômica. (...) Limitar gastos sociais significa limitar a redução de desigualdades. A Oxfam Brasil acredita que a Emenda do Teto de Gastos é um dos mais graves retrocessos observados no Brasil desde a Constituição, e um largo passo para trás na garantia de direitos (OXFAM, 2017, p. 59).

Num contexto de crise fiscal, em que o debate sobre saneamento das contas públicas leva, invariavelmente, à alternativa quase que única do corte de gastos públicos, especialmente os sociais, acaba tendo um forte impacto no problema do descumprimento das metas do PNE, dentre as quais o da institucionalização do SNE. Essa Emenda interdita o debate federativo durante 20 anos, razão pela qual ela, por si só, representa não apenas um entrave à institucionalização do SNE, mas ao PNE como um todo, na medida em que constitui um ataque ao próprio modelo de Estado Social adotado pela CF/88.

A proposta de enxugamento do papel distributivo do Estado ataca o que constitui a essência de um PNE, qual seja, projetar mudanças estruturais para o futuro, esvaziando seus mecanismos de financiamento, que poderiam promover, de modo concreto e significativo, o objetivo de redução das desigualdades educacionais existentes no país de modo planejado e vinculante.

Diante do quadro de retrocesso em matéria de financiamento dos direitos sociais em função do novo regime fiscal instituído pela EC 95/2016, num quadro de limitação de recursos públicos, como articular e financiar as 10 diretrizes, 20 metas e 254 estratégias a serem cumpridas durante dez anos por 5570 municípios, 26 estados, um Distrito Federal e a União?

Há pelo menos duas concepções dissonantes em torno da avaliação da possibilidade de cumprimento do PNE, em face da ausência do SNE: uma defendida pela Campanha Nacional pelo Direito à Educação (CNDE) e outra pelo 
Movimento Todos pela Educação (MTPE). Para a CNDE, a falta de institucionalização do SNE acaba comprometendo o cumprimento integral de todas as metas do PNE. Isso porque tal entidade concebe o plano como uma agenda encadeada, em que um dispositivo alimenta o outro. Em consequência, quando se observa o atraso no cumprimento de um dispositivo, os demais dispositivos ficam comprometidos.

Já o MTPE apresenta uma visão de certa forma mais pragmática em relação à avaliação dos níveis de cumprimento do PNE. Consideram que o PNE estabelece uma relação de obrigações e deveres, traduzidas em metas e estratégias presentes nos dispositivos da lei 13.005/14. Diante dessa perspectiva, a falta de institucionalização do SNE não comprometeria o cumprimento de todas as demais metas do PNE, pois a execução do plano deve ser avaliada, segundo essa concepção, por meta estabelecida (MARTINS, 2014).

Levando-se em conta o conceito aqui adotado, formulado por Saviani, acreditase que, para se constituir um sistema, não basta apenas reunir, sendo necessário também ordenar e articular elementos que fazem parte de um todo em torno de finalidades comuns (SAVIANI, 2010). Assim, partindo-se do pressuposto de que o SNE tem por grande objetivo traçar os contornos da cooperação interfederativa e criar os mecanismos que garantirão a gestão compartilhada entre União e entes federados, articulando as diferentes esferas federativas de governo em torno do cumprimento de suas responsabilidades comuns, acredita-se que a sua ausência afetará sobretudo a execução das metas atribuídas àqueles municípios que não têm recursos próprios suficientes para financiá-las, já que as mesmas dependem da ampliação expressiva da complementação da União. Sem o SNE, dada a inexistência de um dispositivo federativo que garanta essa forma de cooperação, e sem recursos suficientes, como fazer com que o PNE não vire apenas uma "carta de intenções", como de certa forma ocorreu com o PNE 2001-2010?

Na prática, sem o SNE, o cumprimento da meta 20, que trata do aumento progressivo do investimento em educação até chegar ao valor correspondente a $10 \%$ do PIB, acaba comprometendo o financiamento de todas as demais metas do PNE que trazem perspectivas de avanço para a educação brasileira, pois elas dependem do aumento da aplicação de recursos (MARTINS, 2014). No próximo tópico, pretendemos discutir, para além do problema financeiro, os principais obstáculos à institucionalização do SNE no Brasil.

\section{Os adversários históricos:}

Para além dos fatores de ordem econômico-financeira presentes no cenário atual, acima sintetizados, segundo Carlos Jamil Cury (2013), a incorporação em nosso ordenamento jurídico de um SNE conta com três grandes adversários históricos: o setor privado, a União e os estados membros. Serão apresentados, em seguida, os principais argumentos que vêm embasando o posicionamento de cada 
um desses atores, com o objetivo de se verificar se são de fato consistentes ou não, em especial à luz do atual ordenamento jurídico brasileiro.

\subsection{O setor privado}

O embate histórico entre o setor público e o setor privado no campo educacional não é novidade no cenário jurídico brasileiro, tendo se refletido nos debates da Assembleia Nacional Constituinte (1987-88). De um lado estavam os que defendiam a criação de um sistema educacional público, gratuito, universal e de qualidade, por meio da garantia da destinação de recursos públicos exclusivamente para as escolas públicas. De outro, os que pretendiam uma maior participação da área privada na oferta de serviços educacionais, relegando ao Estado a mera regulamentação do setor, garantindo-se a concessão de subsídios, isenções fiscais e outros mecanismos para fomentar essa participação. Segundo a visão privatista, a adoção da forma de estruturação da educação como sistema deveria ser rechaçada, pois poderia vir a abrir caminho para o monopólio dessa atividade pelo Estado. (COMPARATO, 1987).

O texto constitucional de 1988 acabou refletindo a polêmica existente em torno do tema, pois ao mesmo tempo em que garantiu a gratuidade do ensino público em estabelecimentos oficiais (cf. art. 206, IV), previu mecanismos de isenções tributárias e aportes diretos de recursos financeiros para estabelecimentos privados de ensino, ainda que limitados às escolas comunitárias, confessionais ou filantrópicas (cf. art. 213).

Por outro lado, a CF/88 conferiu à educação, de modo expresso, o status de direito fundamental (cf. art. $6^{\circ}$ ), o que significa que a sua oferta não está no campo da livre iniciativa empresarial, não podendo ser tratada como uma mercadoria ou produto qualquer. Segundo Comparato (1987, p. 112), a sua prestação, em todos os níveis, deve ser reconhecida como um serviço público, exigindo a competente delegação administrativa quando oferecida pelo setor privado. Dessa forma, se esse serviço público for realizado por particular, isso implicará, consequentemente, a sua sujeição à fiscalização pelo poder público quanto ao atendimento dos princípios e objetivos educacionais estabelecidos pela $\mathrm{CF} / 88$.

Note-se que o ordenamento jurídico brasileiro está longe de estabelecer o monopólio da prestação de serviços educacionais ao Estado. Contudo, é função, aí sim exclusiva do setor público, o dever de editar normas válidas para todo o conjunto de instituições, públicas e privadas, que atuam no setor educacional, no sentido de garantir a unidade do todo em torno da persecução de valores e objetivos comuns (como o da própria qualidade da educação).

O embate histórico entre o setor público e o setor privado no campo educacional esteve presente, mais recentemente, quando se discutiu, na Câmara dos Deputados, o texto do dispositivo da Lei 13.005/2014, que trata da Meta 20 do PNE, acima mencionada. A redação do dispositivo inicialmente aprovado propunha a 
ampliação do investimento público em educação pública de forma a atingir, no mínimo, o patamar de $7 \%$ do PIB do país no quinto ano de sua vigência e, no mínimo, o equivalente a 10\% do PIB ao final do decênio. Contudo, essa redação foi alterada no Senado, cujo substitutivo retirou a expressão "pública" e acrescentou a remissão ao que se transformou no art. $5^{\circ}$, parágrafo $4^{\circ}$ da Lei $13.005 / 2014$, que prevê:

O investimento público em educação a que se refere o art. 214, inciso VI, da Constituição Federal, e a Meta 20 do anexo desta lei, engloba os recursos aplicados na forma do art. 212 da Constituição Federal e do art. 60 do Ato das Disposições Constitucionais Transitórias, bem como os recursos aplicados nos programas de expansão da educação profissional e superior, inclusive na forma de incentivo a isenção fiscal, as bolsas de estudos concedidas no Brasil e no exterior, os subsídios concedidos em programas de financiamento estudantil e o financiamento de creches, pré-escolas e de educação especial na forma do art. 231 da Constituição Federal.

Houve, na prática, a abertura da possibilidade de se "contabilizar os recursos de isenções fiscais que financiam programas como o Prouni e o Pronatec, ou empréstimos que compõem o Fies na meta de investimento público em educação" (MARTINS, 2014). O que isso significa em termos de recursos que deixarão de ser aplicados diretamente em educação pública? Difícil saber, pois:

A meta do financiamento educacional faz parte do conjunto de metas do PNE que ainda não têm indicadores oficiais definidos para o adequado monitoramento. O texto da meta 20 é explícito ao indicar que deve ser considerado o investimento público em Educação pública, ou seja, o investimento público direto. Contudo, o parágrafo $4 \circ$ do Art. $5 \circ$ da Lei do PNE determina que o investimento público em Educação a que se refere à meta 20 engloba também os recursos aplicados nos programas e subsídios de expansão da Educação Profissional e Superior, bolsas de estudos no Brasil e no exterior e o financiamento de creches, pré-escolas e escolas de Educação Especial privadas (conveniadas com o poder público) (...) O Inep/MEC tem recentemente envidado esforços para construir indicadores precisos, atualizados e afinados com as disposições do PNE, mas ainda não há previsão de conclusão dos estudos nessa linha. (TODOS PELA EDUCAÇÃO, p. 123) 
Mas uma coisa é certa. Se é verdade que, durante os debates que antecederam a adoção do PNE 2014-2024, houve um acordo em relação à necessidade de se ampliar os recursos públicos para a educação (a Meta 20 do PNE é um exemplo disso), também é verdade que, diante da expectativa de aumento de recursos públicos para a educação, houve uma disputa política sobre quem poderia se aproveitar desses recursos. Nesse caso, a introdução do parágrafo $4{ }^{\circ}$ ao art. 5• da Lei do PNE representou uma vitória do setor privado.

Isso porque o dispositivo acrescentado ao art. $5^{\circ}$ da Lei 13.005/14, ao autorizar a contabilização de recursos públicos destinados à iniciativa privada (na forma de subsídios, convênios e bolsas de estudos) no cálculo para se atingir o montante de $10 \%$ do PIB a ser aplicado em educação, representou uma redução dos recursos públicos diretos para a escola pública. Frustrou-se, assim, a tentativa, por parte dos defensores do direcionamento dos recursos públicos exclusivamente para a escola pública, que não conseguiram evitar que a expansão do setor privado se desse às custas dos recursos inicialmente destinados para a educação pública. Mais uma vez, o resultado mostra como estamos longe de um sistema de monopólio estatal no campo educacional.

Na realidade, desde o Manifesto de 1932, a ideia de institucionalização de um sistema nacional de educação nunca representou o perigo concreto do monopólio da educação pelo Estado; tampouco a demonização da participação do setor privado nessa área. Vale lembrar que a liberdade de ensino sempre esteve presente em todas as constituições brasileiras, seja nos períodos autoritários, seja nos períodos democráticos. O projeto defendido pelos escolanovistas de universalização da educação pública, gratuita, laica, de qualidade e democrática, por meio da institucionalização de um SNE efetivo, visava obrigar a União a organizar, dirigir, regular, controlar e articular a atuação dos elementos que compõem as redes pública e privadas, no âmbito municipal, estadual e federal, sempre no sentido de garantir que o direito à educação de qualidade não fosse privilégio de poucos.

\subsection{A União (ou a polêmica entre centralização versus descentralização em matéria educacional)}

Foi dito acima que um dos objetivos da institucionalização de um SNE é fazer com que a responsabilidade pela oferta de uma educação de qualidade não recaia sobre estados e municípios, sem os aportes financeiros correspondentes da União. Dessa forma, busca-se contribuir para a redução das desigualdades em matéria de oferta de prestações educacionais entre municípios e estados menores ou mais pobres e municípios e estados com maior arrecadação.

Nesse sentido é que CURY (2013) aponta a União como segundo adversário histórico à institucionalização do SNE no Brasil. O principal obstáculo, segundo o 
autor, fundamenta-se no temor do aumento da participação deste ente federativo no financiamento da educação nacional.

Por trás dessa discussão a respeito do papel da União no federalismo educacional brasileiro está um outro antigo embate histórico que opõe centralização e descentralização, numa tensão permanente e continuada, comum numa República Federativa como a brasileira, em que os níveis de desigualdades de conformação entre os entes federativos são gritantes (ABICALIL, 2012).

Sobretudo a partir da década de 1990, em que o processo de descentralização em matéria educacional foi bastante intenso, os municípios assumiram inúmeras responsabilidades e atribuições com as quais muitas vezes não têm condições de arcar, principalmente aqueles menores e mais pobres. Essa relação desproporcional entre o amplo rol de obrigações assumidos pelos municípios e a existência de recursos próprios suficientes para atendê-los trouxe um impacto negativo sobre a qualidade dos serviços ofertados, contribuindo não apenas para a manutenção, como para o aprofundamento das desigualdades em matéria educacional existentes no país.

No Brasil, a decisão de descentralizar está, irremediavelmente, ligada à questão histórica das desigualdades regionais, que nunca foram encaradas como prioridade nacional máxima. Desta forma, sem uma real preocupação com as desigualdades regionais os efeitos da própria descentralização se tornam limitados. E na questão das disparidades regionais, o papel da União é fundamental: os entes federados não podem suprir o planejamento e decisões que exigem visões supra regionais, nem têm como obter, isoladamente, grandes recursos. Os efeitos da repartição de rendas e encargos foram diferentes nas várias regiões, dado totalmente ignorado pelo Governo Federal, que não pode ser subsidiário (como querem alguns), patrocinando o desmonte de políticas públicas. É a problemática das desigualdades regionais que deve determinar os limites da descentralização no Brasil, questão esta que, no processo descoordenado de descentralização que vem ocorrendo no Brasil, foi deixada de lado. (BERCOVICI, 2003, p. 183)

Como resultado dessas políticas e, na ausência de um SNE capaz de suprir as carências das localidades mais pobres, formou-se um quadro de grandes disparidades entre os serviços educacionais prestados pelos diversos entes federados, com a tendência de os municípios mais pobres oferecerem serviços educacionais de pior qualidade, fenômeno que não ocorreu da mesma forma, nem com a mesma intensidade, na área da saúde, por exemplo, que optou pela criação de um sistema, como vimos, desde os debates que antecederam a promulgação da 
atual Constituição. Arretche (2013) atribui o melhor desempenho na área da saúde à existência do SUS e ao papel da União na compensação das desigualdades.

O estudo de Arretche (2013) mostra a importância do papel redistributivo da União na redução das desigualdades interjurisdicionais de receitas e, por consequência, na redução das desigualdades de acesso dos cidadãos a serviços públicos no interior de um Estado nação. Isso porque, na ausência de transferências por parte da União, a capacidade de os municípios brasileiros proverem serviços públicos torna-se altamente desigual. Em consequência, a autora defende a tese de que, quanto mais reguladas nacionalmente forem as políticas, menos desiguais serão os seus efeitos.

Isso porque, sendo os municípios brasileiros muito desiguais em termos de arrecadação, sua capacidade de provimento dos serviços também será muito desigual, o que poderá ser compensado - desde que com o repasse de recursos correspondentes - com maior regulação federal:

(...) em uma federação que não conseguiu efetivar o Estado de BemEstar Social proposto pela Constituição de 1988, a necessidade de acesso a bens e serviços é ainda mais aguda. Somado a isso, para uma federação assimétrica como a brasileira, descentralizar atribuições sem a correspondente alocação de recursos significa condenar parte dos cidadãos a uma dupla exclusão. De um lado, são excluídos dos benefícios do progresso econômico de seus territórios e, de outro, residem em territórios que não possuem capacidade financeira para fornecer serviços públicos que minimizem a exclusão e favoreçam melhores condições de inserção no mundo moderno (ARAÚJO, 2013, p. 254).

Nesse sentido, a normatização do SNE seria um avanço no combate e na reversão dos efeitos da cultura das políticas descentralizadoras, que dominaram o cenário educacional, sobretudo a partir da década de 1990, dentre as quais se destaca a instituição do FUNDEF, por meio da EC 14/1996. Tal medida teve grande impacto no cenário educacional brasileiro, tendo como foco a subvinculação de recursos direcionados a uma das etapas da educação básica - o ensino fundamental obrigatório, na contramão do que se entende por uma visão sistêmica da educação e, ainda, sem alterar estruturalmente o quadro tributário (DOURADO, 2013, p. 770).

Esse processo sofreu uma inflexão com a Emenda Constitucional n. 53/2006, que introduziu o FUNDEB, momento em que houve o rompimento com a lógica da focalização no ensino fundamental obrigatório anteriormente adotada. Mais do que isso, com o FUNDEB a participação da União no financiamento da educação básica teve uma sensível melhora, sobretudo com a inserção do dispositivo de participação percentual da União no novo fundo, fruto de pressões da sociedade 
civil. Além disso, Cruz e Jacomini (2017) destacam como ponto positivo do FUNDEB o estabelecimento do dever de reorganização dos conselhos de controle e acompanhamento social, visando a inserção de mecanismos para maior efetividade do fundo.

O aumento da abrangência da lei, que passa a beneficiar não somente o ensino fundamental, mas toda a educação básica - o que inclui parte da educação infantil (pré-escola), o ensino fundamental e o médio - é ressaltado por autores como Davies (2006), Cury (2010) Gouveia e Souza (2014), Taporosky (2016) e Cruz e Jacomini (2017) e Araújo (2007) como um dos principais avanços do FUNDEB em relação ao FUNDEF. Contudo, esse fundo não contempla novas fontes de financiamento da educação, mas sim, redistribui as receitas já existentes na Constituição Federal, no que tange aos estados, Distrito Federal e aos municípios, o que pode ser considerada uma limitação desse fundo.

Mas talvez a maior fragilidade do FUNDEB resida no fato de o mesmo não estar suficientemente institucionalizado em nosso ordenamento jurídico, pois sua vigência se encerrará em 2020 e, até o momento, não se sabe o modelo que irá substituí-lo:

No dia 31 de dezembro de 2020 se encerrará a vigência da Emenda Constitucional no 53/2006 e antes deste prazo será necessário que o Estado Brasileiro, com a participação de todos os entes federados e da sociedade civil, apresentem não somente um balanço dos efeitos de 24 anos de política de fundos (dez do Fundef e quatorze do Fundeb), como também qual será o formato redistributivo para o próximo período (ARAUJO, 2013, p. 256).

Esse seria o momento para promover uma mudança no atual modelo da política de fundos, de modo a se obter resultados mais significativos em termos de redução das desigualdades, compatíveis com o cumprimento das metas previstas no PNE 2014-2024. Para tanto, ao invés de um percentual dos depósitos (o que já representou um avanço do FUNDEB em relação ao FUNDEF), uma das propostas mais consistentes e coerentes com a $\mathrm{CF} / 88$, seria atrelar a participação da União à necessidade de se complementar os fundos estaduais (ou um fundo único) com os valores suficientes para prover os insumos necessários a uma educação de qualidade (ARAÚJO, 2013, p. 253; 255), tal como previsto no art. 206 da CF/88:

Apesar de ser norma constitucional desde 1988 e aparecer com frequência na legislação educacional, o padrão mínimo de qualidade não foi priorizado e sofre enorme resistência para a sua operacionalização. O estabelecimento de um dado padrão de qualidade obrigatório para todos os sistemas de educação deixaria expostos os limites do financiamento educacional atual (...). A 
existência de um padrão mínimo exigiria esforço conjunto dos entes federados para cumpri-lo e forçaria uma rediscussão do aspecto apenas supletivo da ajuda federal (ARAÚJO, 2013, p. 255).

A falta de consenso em torno da determinação do conteúdo do princípio da qualidade da educação e da metodologia a ser utilizada para a regulamentação do CAQi, acima mencionada, além das indefinições quanto à política do novo FUNDEB, parecem estar ligados a um mesmo fenômeno. Trata-se de mais uma manifestação que ilustra a resistência histórica em relação à adoção de mecanismos que resultam no aumento significativo da responsabilidade da União pela educação básica nacional ${ }^{3}$.

De fato, a regulamentação, no âmbito educacional, do federalismo cooperativo previsto na $\mathrm{CF} / 88$ induz ao protagonismo da União no exercício de sua função de promoção do princípio da igualdade material, por meio do direcionamento e da oferta de políticas públicas, de modo a alcançar os objetivos de redução das desigualdades sociais e regionais do país.

Embora a ampliação do papel redistributivo da União possa ser considerada até mesmo como um imperativo constitucional, estando plenamente de acordo com o espírito solidário e o caráter colaborativo entre os entes federativos que a $\mathrm{CF} / 88$ buscou implementar, diante do novo regime fiscal inaugurado pela EC 95/2016, o cenário atual parece apontar muito mais para o desmonte do Estado Social e a retração dos gastos da União com políticas sociais como um todo, dentre as quais as educacionais, do que para a sua ampliação.

\subsection{Os estados e o receio de perderem sua autonomia}

Além do setor privado e da União, é preciso mencionar, ainda, o terceiro adversário histórico à institucionalização do SNE mencionado por CURY (2013): os estados. Segundo o autor, a oposição destes entes federativos baseia-se no temor de que, se houvesse a criação do sistema nacional de educação, eles perderiam a sua autonomia e, consequentemente, a possibilidade de legislar em temas como gestão democrática e valorização dos professores.

Ora, uma das características de nossa República federativa consiste justamente no fato de a Constituição reconhecer a competência da União para legislar em matéria de diretrizes e bases da educação comuns a toda nação, sem excluir a competência dos estados para legislar a respeito do tema, de modo a contemplar as suas especificidades, preservando, assim, a sua própria identidade:

\footnotetext{
${ }^{3}$ Na tramitação da PEC de renovação do FUNDEB, no Congresso Nacional, o principal ponto de discórdia é a complementação da União, tanto no que se refere a valor, como à forma de pagamento. Vide nesse sentido a reportagem abaixo, que embora não possua cunho científico, tem um teor informativo: https:/g1.globo.com/educacao/noticia/2019/09/19/mec-retira-apoio-deproposta-que-preve-fundeb-permanente-com-40percent-de-recursos-da-uniao.ghtml
} 
(...) a construção de um Sistema Nacional de Educação nada tem de incompatível com o regime federativo, pois o que é a Federação senão a unidade de vários estados que, preservando suas respectivas identidades, se articulam para assegurar interesses e necessidades comuns? E não é exatamente por isso que a instância que representa e administra o que há de comum entre os vários entes federativos se chama, precisamente, União? Ora, assim sendo, a Federação postula, portanto, o sistema nacional que, no campo da educação, representa a união dos vários serviços educacionais que se desenvolvem no âmbito territorial dos diversos entes federativos que compõem a Federação. (SAVIANI, 2010).

A normatização do SNE não visa sufocar a autonomia, nem as especificidades dos entes federativos. Nesse sentido, a institucionalização de um SNE não deve de modo algum representar a imposição de um currículo único por parte da União, mas deve funcionar como um mecanismo capaz de assegurar que parte do currículo seja nacional (e, portanto, comum a todos), permitindo-se que haja uma identidade nacional, e parte seja definida pelos estados e municípios, respeitandose sua autonomia, diversidade e suas especificidades, tanto regionais quanto locais (MARQUES, 2015).

O conceito de formação básica comum com respeito a valores culturais e artísticos, nacionais e regionais foi previsto no art. 210 da CF/88 e nos artigos 26 e 27 Lei 9394/96 (LDB), mas foi somente a partir da lei 13.005/14, a Lei do PNE, que a determinação de elaboração de uma Base Nacional Comum Curricular (BNCC) foi inscrita de modo explícito na legislação brasileira. Deve-se notar que a estratégia 7.1 do PNE, ao mencionar o dever de "estabelecer e implantar, mediante pactuação interfederativa, diretrizes pedagógicas para a educação básica e a base nacional comum dos currículos, com direitos e objetivos de aprendizagem e desenvolvimento dos (as) alunos (as) para cada ano do ensino fundamental e médio, respeitada a diversidade regional, estadual e local" representa justamente um dos objetivos centrais do SNE, qual seja, fortalecer a unidade nacional e a responsabilidade da União com a educação e, ao mesmo tempo, garantir o respeito à diversidade cultural que caracteriza o país.

Afinal, tal como previsto na conceituação de Saviani:

(...) sistema não é unidade da identidade, uma unidade monolítica, indiferenciada, mas unidade da diversidade, um todo que articula uma variedade de elementos que, ao se integrarem ao todo, nem por isso perdem a própria identidade. Ao contrário, participam do todo, integram o sistema, na forma das respectivas especificidades. 
Em outros termos: uma unidade monolítica é tão avessa à ideia de sistema como uma multiplicidade desarticulada. (SAVIANI, 2010).

Nesse contexto, a criação de um SNE não deve colocar em segundo plano a ação dos entes federativos, mas ao contrário, deve fortalecê-la por meio do estabelecimento de diretrizes nacionais como garantia de direitos (DOURADO, 2013, p. 767), criando-se um paradigma que supõe uma articulação federativa nacional, com importante papel coordenador, indutor e financiador nas mãos da União, mas com grande autonomia dos governos subnacionais.

Se a coordenação federativa redundar em centralização de decisões e poderes na União em detrimento da autonomia dos demais entes federados, não se estaria caminhando para um verdadeiro sistema nacional de educação, muito menos para a concretização do federalismo cooperativo previstos em nossa $\mathrm{CF} / 88$. Por outro lado, a construção de um modelo descentralizado, desvinculado de uma política nacional e das condições para a sua efetivação, levaria ao aprofundamento das disparidades educacionais existentes em nosso país, iniciativa que também estaria na contramão das finalidades atribuídas ao SNE pelo ordenamento jurídico brasileiro:

A instituição do SNE e a regulamentação do art. 23 da Constituição Federal relativo ao regime de colaboração em Educação são fundamentais para o avanço das políticas educacionais e devem resultar em novos marcos de ação e relação entre os entes federativos, sem descurar de normas e diretrizes nacionais, bem como em garantia constitucional de autonomia dos entes federados (RONCA; ALVES, 2015).

Segundo ABRUCIO, FRANZESE e SANO (2010), para a garantia do funcionamento adequado do modelo de federalismo cooperativo, devem ser criadas formas de colaboração entre os entes federativos e arenas intergovernamentais de discussão e deliberação, na forma de conselhos horizontais e verticais. No âmbito da do SUS, as Comissões Intergestores funcionam como um espaço institucional para discussão, entre os entes federativos, dos critérios para redistribuição de parte dos recursos de um fundo público único, o que contribui para a compensação dos desequilíbrios interfederativos (ARAUJO, 2016).

Na ausência da normatização do SNE e diante da deficiência de instâncias interfederativas de pactuação, estados e municípios ficam sem espaços institucionais para que possam apontar situações em que se exige a necessidade de modulação do grau de centralização ou descentralização das políticas adotadas, cobrando, quando necessário, uma maior atuação da União para compensar as desigualdades existentes na sociedade. A insuficiência de canais que possam dar vazão a diálogos interfederativos inibe, ainda, o debate em torno de formas de 
cooperação específicas para superar situações de desigualdades existentes em nosso país. Isso leva à aplicação das mesmas fórmulas para qualquer estado ou município brasileiro, que não raro apresentam demandas bastante distintas (ABICALIL, 2012).

Do ponto de vista dos estados, a institucionalização de um sistema, acompanhada do estabelecimento de mecanismos de coordenação intergovernamental, contribui para o exercício da função coordenadora e articuladora entre tais entes federativos e os municípios:

(...) a visão coordenadora que vem se instalando nos sistemas federativos de políticas públicas aponta na direção de uma negociação constante com estados e municípios autônomos, tanto na elaboração quanto na implementação dos programas governamentais. O que vem sendo feito, com maior ou menor sucesso em diversos setores, é o estabelecimento de mecanismos de coordenação intergovernamental, por intermédio de normas com validade nacional; e a indução à assunção de tarefas, por meio da redistribuição de recursos entre as esferas de governo e de instrumentos de auxílio financeiro condicionado às municipalidades. Entretanto, como a maior parte destas ações vem da União, os Estados brasileiros ainda não assumiram um papel coordenador junto aos municípios, tal qual acontece em diversos países federativos, o que geraria maior equilíbrio intergovernamental (ABRUCIO; FRANZESE; SANO, 2010, p. 198199).

Na visão de CURY (2013), os argumentos apresentados pelos estados como obstáculos à institucionalização de um SNE não são consistentes, pois historicamente a criação de um sistema no âmbito da educação não teve como objetivo acabar com a autonomia dos estados. Isso pode ser constatado, segundo o autor, nos anais da Constituinte de 1934 e nas discussões que antecederam a elaboração do Planos de Educação formulados por Anísio Teixeira na década de 1960.

Para Anísio Teixeira (1994, p. 151), a elaboração de um SNE não deveria se traduzir na imposição de um modelo de escola pelo centro, mas deveria ser produto das condições locais e regionais, devendo ser planejada e realizada "sob medida para a cultura da região, diversificada, assim, nos seus meios e recursos, embora una nos seus objetivos e aspirações comuns". Anísio afirmava que o Plano Nacional deveria fixar metas gerais a serem atingidas por todos, assegurando unidade de ação, mas que sua execução deveria ser descentralizada, confiando aos estados a tarefa de articular e integrar os respectivos serviços de ensino com os serviços municipais. 
Sem perder de vista o cumprimento a uma das tarefas mais importantes de um Estado Democrático, qual seja, a de oferecer a todos iguais oportunidades educacionais, Anísio, ao comentar o dever de desdobramento do PNE de 1961 em planos estaduais e municipais de educação, defendia que os estados deveriam assumir uma posição de liderança, por estarem mais livres das influências, "por vezes estreitas dos governos municipais, ainda demasiado imbuídas, salvo exceções, do velho espírito oligárquico e privatista que importa erradicar" (TEIXEIRA, 1994, p. 151). A ideia, portanto, não era reduzir o papel dos estados, mas fortalecer o seu papel no quadro do federalismo brasileiro, protegendo-o das influências oligárquicas e clientelistas que marcaram a história do país.

\section{A cultura da descontinuidade de políticas públicas}

O estabelecimento de direções claras para as políticas educacionais brasileiras marcadas pela lógica da descontinuidade de iniciativas, fragmentação de programas, ausência de articulação institucional entre redes de ensino e órgãos gestores, carência de planejamento de longo prazo e de recursos proporcionais à realização de suas metas e objetivos (RONCA; ALVES, 2015) - constitui uma das vantagens do estabelecimento de um Plano Nacional de Educação efetivo.

Nesse sentido, a proposta de articulação do SNE como objetivo central do PNE 2014-2024 constitui um avanço, na medida em que prevê, por meio de uma emenda constitucional, a introdução de um arranjo jurídico-institucional que busca contribuir para a consolidação de uma política de Estado para o Brasil no âmbito educacional. Diferentemente das políticas de governo, muitas das quais não resistem à troca de gestões governamentais e, às vezes, nem mesmo à troca de ministros ou secretários de educação no âmbito de um mesmo governo, as políticas de Estado pretendem-se mais duradouras.

O fato de a cada troca de governo haver mudanças significativas nos objetivos, metas e estratégias das políticas públicas adotadas pela gestão anterior, principalmente aquelas que não estão suficientemente institucionalizadas, é um fenômeno comum, ainda que represente um dos principais obstáculos ao êxito de uma política pública. Afinal, não é raro que cada novo governo, ao assumir o poder, queira imprimir a sua própria marca na gestão da coisa pública (BUCCI, 2013).

Contudo, a falta de institucionalização do SNE não constitui um mero problema ligado à margem de discricionariedade na escolha do conteúdo de uma política pública (o programa de ação governamental que ela veicula). Tal omissão configura uma ofensa a um dispositivo constitucional que, ao mesmo tempo, constitui, ele próprio, simultaneamente uma política de Estado e um instrumento garantidor de políticas de governo.

Como consequência, tal lacuna acaba perpetuando uma situação que vem comprometendo a criação de novas formas e estratégias articuladas de intervenção estatal para garantir que todos os entes federativos atuem de forma cooperativa em matéria educacional, tal como previsto pela $\mathrm{CF} / 88$. 
Sem o SNE, deixa-se de criar ou consolidar instâncias de articulação permanentes entre as esferas da federação, necessárias para que as decisões relevantes sejam tomadas de modo conjunto, para além dos interesses que se se materializam no curto prazo. Deixa-se, portanto, de implementar ferramentas concretas que poderiam vir a contribuir para a melhoraria do funcionamento do modelo federativo educacional atual, impactando na concretização de diversos programas de ação governamental.

Apesar da relevância do SNE para a consolidação de uma política de Estado no âmbito da educação, evitando-se a descontinuidade de programas de ação governamental a cada troca de gestão, mais uma vez na história educacional do país, o dever de sua institucionalização, mesmo tendo sido pela primeira vez previsto no instrumento jurídico da mais alta hierarquia do ordenamento jurídico brasileiro, corre o risco de ter sua concretização adiada indefinidamente, conforme acima mencionado, ou, ainda que venha a ser regulamentado num futuro não muito distante, as chances de que isso ocorra sem o esvaziamento das condições financeiras para que o SNE possa vir a cumprir o seu papel, não parecem estar no horizonte político atual.

Enquanto tal regulamentação não ocorre, continuamos a observar a prevalência das inúmeras contradições, imprecisões e improvisações que vêm marcando a regulamentação da educação no Brasil (SAVIANI, 2010). O cenário atual parece apontar para a manutenção de uma cultura política avessa ao planejamento de longo prazo de modo a se alcançar a realização do dever de solidariedade, que constitui a base do federalismo cooperativo previsto em nossa CF/88.

Um dos exemplos desses retrocessos pode ser constatado quando se verifica o esvaziamento ou enfraquecimento dos mecanismos de monitoramento contínuo da aplicação e de avaliações periódicas de seu cumprimento, que deveriam ser realizadas pelo Ministério da Educação, pelas Comissões de Educação da Câmara e do Senado, pelo Conselho Nacional de Educação (CNE) e pelo Fórum Nacional de Educação.

\section{CONSIDERAÇÕES FINAIS}

Depois de tantas idas e vindas, pode-se dizer que nunca estivemos tão próximos da institucionalização de um SNE no Brasil. Do ponto de vista jurídico, não há nada que justifique o engavetamento de um plano de ação governamental expresso em uma lei aprovada por unanimidade pelo Congresso Nacional, sancionada sem vetos pelo Poder Executivo, e precedida de um amplo debate democrático, com extensa participação social dos setores envolvidos com essa temática.

A existência de mecanismos jurídicos para fazer valer os direitos previstos no PNE não suscita dúvidas, pois estes estão devidamente ancorados em instrumentos normativos, não sendo possível questionar sua base jurídica, contando-se, inclusive, no caso específico do SNE, com a previsão de um prazo específico para a criação, o que não é comum nesse tipo de dispositivo legal. 
Tais fatores, contudo, não foram suficientes para inibir a inércia governamental e uma série de retrocessos significativos em matéria de efetivação de direitos sociais, dentre os quais aqueles previstos no PNE 2014-2024. Isso parece indicar que a resolução de um problema tão complexo como o da ausência da estruturação da educação nacional na forma de um sistema não depende exclusivamente de fatores jurídicos.

O breve panorama dos conflitos de interesses políticos, ideológicos, culturais e econômicos que se expressam ao longo da evolução da proteção constitucional da educação no país nos mostra que tais embates assumem diferentes contornos ao longo do tempo, gerando diferentes respostas, mais ou menos consistentes, mais ou menos conectadas com os anseios dos atores sociais.

Em relação aos interesses do setor privado, como visto, após mudanças na lei do PNE, permitiu-se a transferência de recursos públicos para que os particulares participem da oferta de prestações educacionais, o que indica que seus interesses estão sendo de certo modo preservados, mesmo com a previsão do SNE. Contudo, não se pode desconsiderar que a institucionalização do SNE, pela sua própria finalidade, pode vir a aumentar o risco de correção de distorções na estruturação e no funcionamento do modelo de financiamento da educação hoje existente, ampliando a fiscalização e eventuais limitações para o recebimento de isenções e renúncias fiscais por parte dos particulares, além de representar uma barreira a propostas focadas na privatização dos serviços educacionais no ensino superior, por exemplo. Assim, não há que se desprezar a influência que o setor particular, no cenário atual, representa em relação à institucionalização do SNE no Brasil.

No que se refere aos estados, conforme argumentado por Cury, historicamente a luta pela institucionalização do SNE jamais esteve atrelada ao objetivo de redução de sua autonomia. Muito ao contrário: pode-se dizer que a regulamentação do federalismo cooperativo por meio da institucionalização do SNE poderia vir a garantir o fortalecimento deste ente federativo, criando condições para que sua autonomia se manifeste de modo mais efetivo.

Já o "perigo" de se aumentar o ônus do governo federal em matéria educacional oferecido pela perspectiva da institucionalização de um sistema nacional parece constituir, dentre os fatores apresentados por Cury, aquele que tem maior embasamento para justificar a resistência histórica em torno de sua previsão em nosso ordenamento jurídico.

Isso porque, para se corrigir o quadro de desigualdades acima apontado, democratizando e melhorando a qualidade das oportunidades educacionais no Brasil, a ampliação, de forma efetiva, da participação da União é fundamental. Acredita-se, tal como defendido por CURY, que, dos temores dos três atores apresentados em relação à institucionalização do SNE, o que tem maior embasamento provavelmente seja de fato o da União, pois é ela que tem o ônus financeiro de arcar com as obrigações que decorram do dever de oferta de um 
ensino com padrão de qualidade mínimo em todo o território nacional, compensando as desigualdades educacionais existentes em nosso país.

A regulamentação, no âmbito educacional, do federalismo cooperativo previsto na CF/88 induz, de fato, ao protagonismo da União no exercício de sua função de mediação e promoção do princípio da igualdade material, de modo a alcançar os objetivos de redução das desigualdades sociais e regionais do país. Tal iniciativa encontra grande resistência por parte daqueles que se posicionam de modo contrário à adoção de mecanismos que resultam no aumento da responsabilidade financeira da União no direcionamento e na oferta de políticas públicas educacionais.

$\mathrm{Na}$ realidade, não obstante os avanços introduzidos a partir da $\mathrm{CF} / 88$ nas políticas educacionais, os direitos sociais como um todo deixaram de ser tratados como prioridade nacional nos anos recentes. $\mathrm{O}$ momento atual aponta não apenas para a descontinuidade de políticas de governo ou de Estado no âmbito educacional, mas de um verdadeiro desmonte do modelo de Estado com forte viés social pactuado em 1988, sobretudo por conta de razões de enxugamento do papel redistributivo do Estado e, consequentemente, do corte de recursos financeiros necessários para viabilizar este modelo de Estado.

\section{REFERÊNCIAS}

ABICALIL, Carlos Augusto. O federalismo e o Sistema Nacional de Educação Uma oportunidade fecunda. Revista Retratos da Escola, v. 6, n. 10, 2012, p. 21-37.

ABRUCIO, Fernando Luiz; FRANZESE, Cibele; SANO, Hironobu. Coordenação e cooperação no federalismo brasileiro: avanços e desafios. In: CUNHA, A. S.; MEDEIROS, B. A.; AQUINO, L. C. (Orgs.). Estado, instituições e democracia: República. Brasília, DF: IPEA, v. 1, 2010.

ALVES, João Roberto Moreira. O Plano Nacional da Educação e o papel da sociedade no processo de sua construção coletiva. Carta Mensal Educacional.

Instituto de Pesquisas Avançadas em Educação, ano 18, n. 124, 2010.

ARAUJO, Luiz. Financiamento da Educação Básica no Governo Lula: Elementos de ruptura e continuidade com as políticas do governo de FHC. Brasília:

Dissertação de Mestrado da Faculdade de Educação da Universidade de Brasília, 2007.

ARAUJO, Gilda Cardoso. Federalismo e políticas educacionais no Brasil: equalização e atuação do empresariado como projetos em disputa para a 
regulamentação do regime de colaboração. Educ. Soc. [online]. v. 34, n. 124, p. 787-802, 2013.

ARRETCHE, Marta. Democracia, Federalismo e Centralização no Brasil. Rio de Janeiro: Ed. Fiocruz/Ed. FGV, 2012.

ARRETCHE, Marta. Democracia e Redução da Desigualdade Econômica no Brasil: A inclusão dos outsiders. Rev. bras. Ci. Soc., São Paulo, v. 33, n. 96, 2018. Disponível em: <http://www.scielo.br/scielo.php?script=sci_arttext \&pid=S0102-69092018000100508\&lng=en\&nrm=iso>. Acesso em 28 out. 2019.

AZEVEDO, Fernando de. et al. A reconstrução educacional no Brasil. Ao povo e ao governo. $\mathrm{O}$ manifesto dos pioneiros da educação nova. São Paulo: Ed. Nacional, 1932.

BERCOVICI, Gilberto. A descentralização de políticas sociais e o federalismo cooperativo brasileiro. Revista de Direito Sanitário, v. 3, n. 1, 2002, p. 13-28, 2002.

BERCOVICI, Gilberto. Desigualdades Regionais, Estado e Constituição. São Paulo: Max Limonad, 2003.

BERCOVICI, Gilberto. Planejamento e políticas públicas: por uma nova compreensão do papel do Estado. In: BUCCI, Maria Paula Dallari (org.) Políticas Públicas: reflexões sobre o conceito jurídico. São Paulo: Saraiva, 2004.

BERCOVICI, Gilberto. Constituição Econômica e Desenvolvimento: uma leitura a partir da Constituição de 1988. São Paulo: Malheiros, 2005.

BERCOVICI, Gilberto. The crisis and the topicality of the Welfare State for the periphery of capitalism. Estudos do Século XX, n. 13, 2013, p. 127-144.

BRASIL, Ministério da Educação. Planejando a Próxima Década. Conhecendo as 20 Metas do Plano Nacional de Educação. Brasília: Ministério da

Educação/Secretaria de Articulação com os Sistemas de Ensino (MEC/Sase), 2014.

BUCCI, Maria Paula Dallari. Fundamentos para uma teoria jurídica das políticas públicas. São Paulo: Saraiva, 2013. 
BUCCI, Maria Paula Dallari; COUTINHO, Diogo Rosenthal. Arranjos jurídicoinstitucionais da política de inovação tecnológica: uma análise baseada na abordagem de direito e políticas públicas. In: COUTINHO, Diogo Rosenthal. Inovação no Brasil: avanços e desafios jurídicos e institucionais. São Paulo: Blucher, 2017.

BUCCI, Maria Paula Dallari; DUARTE, Clarice Seixas. Judicialização da Saúde: a visão do Poder Executivo. São Paulo: Saraiva, 2017.

BUCCI, Maria Paula Dallari; GOMES, Fernando Dourado. A piece of legislation for the guidance of public education policies in Brazil: The National Education Plan 2014-2024. The Theory and Practice of Legislation Journal, v. 5, 2017, p. 277301.

COMPARATO, Fábio Konder. Educação, Estado e Poder. São Paulo: Brasiliense, 1987.

\section{CONFERÊNCIA NACIONAL DE EDUCAÇÃO (CONAE). Construindo o} Sistema Nacional articulado de Educação: o Plano Nacional de Educação, diretrizes e estratégias; Documento-Base. Brasília, DF: MEC, 2010

CONFERÊNCIA NACIONAL POPULAR DE EDUCAÇÃO (CONAPE).

Documento Final: Plano de Lutas. Fórum Nacional Popular de Educação, 2018. Disponível em: $<$ http://fnpe.com.br/docs/documentos/docs-conferencia/fnpeconape2018-documento-final-planodelutas.pdf $>$. Acesso em: 26 out. 2019.

CRUZ, Rosana Evangelista da; JACOMINI, Márcia Aparecida. Produção acadêmica sobre financiamento da educação: 2000-2010. Revista Brasileira de Estudos Pedagógicos, v. 98, n. 249, 2017, p. 347-370.

CURY, Carlos Roberto Jamil. A questão federativa e a educação escolar. In: OLIVEIRA, Romualdo Portela; SANTANA, Wagner (Orgs.). Educação e federalismo no Brasil: combater as desigualdades, garantir a diversidade. Brasília: Unesco, 2010.

CURY, Carlos Roberto Jamil. Fundamentos de uma educação para os direitos humanos. Revista do COGEIME, v. 41, 2013, p. 131-144.

CURY, Carlos Roberto Jamil. Do Público e do Privado na Constituição de 1988 e nas Leis Educacionais. Educ. Soc., v. 39, n. 145, 2018, p. 870-889. 
DAVIES, Nicholas. Fundeb: a redenção da educação básica? Educ. Soc, n. 96, v. 27, 2006, p. 753-774.

DOURADO, Luiz Fernandes. Diretrizes curriculares nacionais para a formação inicial e continuada dos profissionais do magistério da educação básica: concepções e desafios. Educ. Soc., v. 36, n. 131, 2015, p. 299-324.

DOURADO, Luiz Fernandes. A institucionalização do sistema nacional de educação e o plano nacional de educação: proposições e disputas. Educ. Soc., v. 39 , n. 143, 2018, p. 477-498.

DRAIBE, Sônia. Rumos e metamorfoses: Estado e industrialização no Brasil (1930-60). Rio de Janeiro: Paz e Terra, 1985.

GADELHA, Regina Maria. Educação no Brasil: Desafios e Crise Institucional. Pesquisa \& Debate, v. 28, n. 1, 2017.

GOUVEIA, A. B.; SOUZA, Â. R. Desafios atuais para o financiamento de uma educação de qualidade. In: PINTO, J. M. R.; SOUZA, S. A. (Orgs.). Para onde vai o dinheiro? Caminhos e descaminhos do financiamento da educação. São Paulo: Xamã, 2014.

MARTINS, Paulo Sena. A política das políticas educacionais e seus atores. Jornal de Políticas Educacionais, n. 15, p. 13-32, 2014.

OXFAM. A distância que nos une: um retrato das desigualdades brasileiras. São Paulo, 2017.

PINTO, José Marcelino de Rezende. O Fundeb na Perspectiva do Custo Aluno Qualidade. Em aberto, v. 98, n. 93, 2015, p. 101-117.

RONCA, Antônio Carlos Caruso; ALVES, Luiz Roberto. O Plano Nacional de Educação e o Sistema Nacional de Educação: educar para a equidade. São Paulo: Fundação Santillana, 2015.

SAVIANI, Demerval. Sistema Nacional de Educação articulado ao Plano Nacional de Educação. Revista Brasileira de Educação, v. 15, n. 44, 2010. 
SAVIANI, Demerval. Política educacional no Brasil após a Ditadura Militar.

Revista Histed, v. 18, n. 2, p. 291-304, 2018.

TAPOROSKY, Barbara Cristina Hanauer. O valor anual mínimo por aluno do FUNDEB, o CAQi e a reserva do possível. Fineduca - Revista de Financiamento da Educação, v. 6, n. 6, 2016.

TEIXEIRA, Anísio. Educação não é privilégio. Rio de Janeiro: Editora UFRJ, 1994. 